\title{
What the neonatologists need to know about the Cantrell's pentalogy
}

\author{
Ce trebuie să știe neonatologii despre pentalogia Cantrell \\ Bianca Mihaela DANCIU ${ }^{1}$, Vlad DIMA², Dora BOGHIȚOIU ${ }^{3,4}$, Ana Maria Alexandra STĂNESCU ${ }^{5}$, \\ Anca Angela SIMIONESCU ${ }^{6,7}$
}

${ }^{1}$ Obstetrică-Ginecologie, Institutul Naţional pentru Sănătatea Mamei şi Copilului „Alessandrescu-Rusescu“, Bucureşti, România

${ }^{2}$ Neonatologie, Spitalul Clinic Filantropia, Bucureşti, România ${ }^{3}$ Spitalul Clinic de Urgenţă pentru Copii „,Grigore Alexandrescu”, Bucureşti, România

${ }^{4}$ Pediatrie, Universitatea de Medicină şi Farmacie „Carol Davila“, Bucureşti, România ${ }^{5}$ Medicină de familie, Universitatea de Medicină şi Farmacie „Carol Davila“, Bucureşti, România ${ }^{6}$ Obstetrică-Gynecologie, Universitatea de Medicină şi Farmacie „Carol Davila“, Bucureşti, România ${ }^{7}$ Obstetrică-Ginecologie, Spitalul Clinic Filantropia, Bucureşti, România

\begin{abstract}
Cantrell's pentalogy is a congenital syndrome that includes multiple defects which predispose the fetus to a high mortality rate. Over time, the association of malformations defining this syndrome has changed accepting incomplete forms, or forms that associate other anomalies.

The therapeutic strategy in Cantrell's pentalogy is an intensely debated one as it deals with newborns having a low survival rate and multiple malformations. Once treatment is started for certain malformations it can lead to the aggravation of others. In conclusion, a conservative approach is recommended, with the initiation of surgical treatment after the stabilization of the newborn. A multidisciplinary approach is needed to achieve optimal results in these difficult cases.
\end{abstract}

Keywords: pentalogy of Cantrell, abdominal wall, cardiac abnormalities

\section{REZUMAT}

Pentalogia Cantrell reprezintă un sindrom congenital ce include defecte multiple ce predispun produsul de concepție la o rată mare de mortalitate. De-a lungul timpului, asocierea de malformații care definesc acest sindrom s-a schimbat, acceptând și forme incomplete sau forme ce asociază și alte anomalii. Strategia terapeutică în pentalogia Cantrell este una intens dezbătută deoarece este vorba de nou-născuți cu o rată mică de supraviețuire și cu malformații multiple, care, odată corectate, pot duce la agravarea celorlalte. In concluzie, se recomandă abordarea conservativă, cu inițierea tehnicilor chirurgicale după stabilizarea nounăscutului și chiar depășirea perioadei neonatale. Este necesară o abordare multidisciplinară, pentru a obține rezultate optime în aceste cazuri dificile.

Cuvinte cheie: pentalogie Cantrell, perete abdominal, anomalii cardiace 


\section{INTRODUCERE}

Pentalogia Cantrell este un sindrom congenital complex rar (1 la 5,5 milioane de feți vii) [1], descris pentru prima dată în 1958 de Cantrell [2]. Acesta se caracterizează prin exprimarea completă sau parțială a 5 anomalii congenitale ale sternului, diafragmului anterior, pericardului, peretelui abdominal anterior și cordului. Inițial, pentru definirea sindromului, erau necesare toate cele 5 defecte, însă în 1972 Toyoma a modificat criteriile de diagnostic, incluzând și cazurile în care defectele sunt exprimate doar parțial [3].

Actualmente, este acceptată și varianta conform căreia criteriile de diagnostic includ și patologii ale cordonului ombilical (mai ales arteră ombilicală unică), care se dezvoltă embriologic în aceeași perioadă cu peretele abdominal și sternul, fiind preluată denumirea de hexalogie Cantrell [4].

Mortalitatea crescută a pentalogiei Cantrell, de 52$61 \%$ [5], ridică probleme de management și tratament, țînând cont de numeroasele implicații vitale pe care le are.

\section{EMBRIOLOGIE}

Din punct de vedere embriologic, dezvoltarea anormală specifică pentalogiei Cantrell are loc încă din primele 8 săptămâni de viață intrauterină. Cel mai probabil, diferențierea celulară specifică acestei perioade, supusă unor mutații genetice și a diferitor factori de mediu, se realizează nerespectând căile clasice ale blastogenezei și organogenezei fiziologice [6,7].

Discul embrionar se diferențiază în cele 3 straturi germinale, ectoderm, mezoderm și endoderm, și suferă cele două mișcări de cudare. Țesuturile germinative încep apoi să se diferențieze pentru a pregăti organogeneza.

Ectodermul se diferențiază în ectodermul de suprafață, ce va da naștere epidermului și neuroectodermului, ce va forma tubul neural.

Mezodermul se diferențiază în mezodermul paraxial, intermediar și lateral, ce va tapeta cavitățile pleurale, pericardice și peritoneale și va da naștere oaselor, cartilajelor, mușchilor, țesuturilor parenchimatoase, vaselor de sânge, sistemului reproducător, excretor și urogenital.

Endodermul se orientează în direcție caudală, dând naștere glandelor endocrine, sistemului respirator și digestiv.

Perturbarea oricăreia dintre aceste faze poate duce la apariția pentalogiei Cantrell. Cantrell a sugerat că tulburările de embriogeneză specifice sindromului apar între a 14-a și a 18-a zi de viață intrauterină, prin migrarea defectuoasă a pliurilor mezodermale spre linia mediană, această explicând de ce toate defectele specifice pentalogiei Cantrell sunt localizate medial și provin din punct de vedere embriologic din mezoderm [1].

TABEL 1. Clasificarea pentalogiei Cantrell după Toyama [3]

\begin{tabular}{|c|c|c|}
\hline Tipul 1 & Tipul 2 & Tipul 3 \\
\hline Exprimarea completă a defectelor & Exprimarea parțială a defectelor & Exprimarea incompletă a defectelor \\
\hline Prezența a 5 defecte complete & Prezența a 4 defecte & Combinații variabile a mai puțin de 4 defecte \\
\hline $\begin{array}{l}\text { 1. Defect al pericardului diafragmatic } \\
\text { 2. Defect al diafragmului anterior } \\
\text { 3. Anomalii congenitale cardiace } \\
\text { 4. Defecte de perete abdominal anterior } \\
\text { 5. Defecte în dezvoltarea sternului, în } \\
\text { special în porțiunea inferioară }\end{array}$ & $\begin{array}{l}\text { Mereu sunt incluse: } \\
\text { 1. Anomalii congenitale cardiace } \\
\text { 2. Defecte de perete abdominal }\end{array}$ & $\begin{array}{l}\text { Mereu sunt incluse defecte în dezvoltarea } \\
\text { sternului, mai ales în porțiunea inferioară }\end{array}$ \\
\hline
\end{tabular}

TABEL 2. Malformaţiile clasice specifice pentalogiei Cantrell [8]

\begin{tabular}{|l|l|l|l|l|}
\hline Defecte pericardice & $\begin{array}{l}\text { Defecte diafragmatice } \\
\text { (în porţiunea sa } \\
\text { anterioară) }\end{array}$ & Anomalii cardiace & $\begin{array}{l}\text { Defecte de perete } \\
\text { abdominal }\end{array}$ & $\begin{array}{l}\text { Defecte în dezvoltarea } \\
\text { sternului }\end{array}$ \\
\hline $\begin{array}{l}\text { Agenezie pericardică } \\
\text { completă }\end{array}$ & $\begin{array}{l}\text { Hernie diafragmatică } \\
\text { congenitală }\end{array}$ & $\begin{array}{l}\text { Defect de sept ventricular (72- } \\
100 \%)\end{array}$ & Omfalocel (74.5\%) & Ectopia Cordis \\
\hline $\begin{array}{l}\text { Agenezie pericardică } \\
\text { parțială }\end{array}$ & Defect de sept atrial (34,6-53\%) & Agenezie sternală \\
\hline & & $\begin{array}{l}\text { Stenoză sau atrezie pulmonară } \\
(31,5-33 \%)\end{array}$ & $\begin{array}{l}\text { Lipsa completă a fuzionării } \\
\text { primordiilor sternale }\end{array}$ \\
\hline & Dextrocardie (15\%) & $\begin{array}{l}\text { Lipsa parțială a fuzionării } \\
\text { primordiilor sternale }\end{array}$ \\
\hline & & Diverticul ventricular (17-50\%) & & \\
\hline & Transpoziție de vase mari (6,3\%) & & \\
\hline
\end{tabular}




\section{MANAGEMENT ȘI STRATEGII TERAPEUTICE}

După naștere, cea mai importantă etapă este stabilizarea nou-născuților cu pentalogie Cantrell. Se aplică tehnici de terapie intensivă neonatală, cu resuscitarea nou-născutului, administrarea de fluide, reglarea statusului hemodinamic și protecție a defectelor prezente. Indicația este de corecție a alterărilor metabolice și hemodinamice, suport ventilator, administrare a medicației inotrope și de fluide pentru a realiza reechilibrarea volemică a pacientului $[9,10]$. În cazul în care sunt prezente și malformații cardiace de tip persistență de canal arterial, se pot administra și prostaglandine. Antibioterapia cu spectru larg trebuie inițiată cât mai precoce pentru a evita riscul ridicat de sepsis al acestor nou-născuți. După stabilizare, trebuie luată o decizie terapeutică în ceea ce privește intervenția chirurgicală. În funcție de caz, se poate opta pentru o intervenție paliativă sau pentru una corectivă [10,11-14].

Închiderea per primam a omfalocelului duce la creșterea presiunii intratoracice și posibilă compromitere respiratorie și cardiovasculară. De aceea, trebuie ales momentul oportun și diminuarea distensiei anselor intestinale prin montarea unei sonde nazo-gastrice sau temporizarea intervenției $[5,15]$. Prin compresia excesivă a cordului, în timpul intervenției de reparare a defectului toracoabdominal, crește riscul de instabilitate hemodinamică și ischemie miocardică $[5,16]$. Și aritmiile sunt frecvent întâlnite tot din această cauză, fiind datorate și compromiterii întoarcerii venoase, dar și scăderii debitului cardiac [18]. Sunt descrise în literatură și episoade de tahiaritmie, hipotensiune, bradicardie și chiar insuficiență cardiacă, în urma intervenției chirurgicale [5,10,11,17-19]. În cazurile de pentalogie Cantrell care prezintă fuziune hepatopulmonară, intervenția chirurgicală este deosebit de dificilă din cauza necesității de separare a celor două structuri [20]. Sunt folosite, în cazul intervențiilor temporizate, soluții de reepitelizare a omfalocelului și menținere a viabilității anselor intestinale utilizând ser fiziologic, clorură de benzalconiu și comprese sterile [21,22].

\section{PROGNOSTIC}

Rata de mortalitate și morbiditate în cazurile de pentalogie Cantrell este extrem de ridicată. Prognosticul variază în funcție de complexitatea defectelor și de numărul acestora [19].

Prognostic infaust prezintă cazurile cu ectopia cordis, hipoplazie pulmonară și alte defecte la nivel cardiac [21,23-26]. Însăși prezența ectopiei cordis singură, fără altă anomalie asociată are o rată de mortalitate între 50\% și 100\% [27,28].

Balanța se înclină în favoarea nou-născuților asupra cărora s-a intervenit chirurgical tardiv și nu s-a realizat închiderea defectelor per primam. Intervenția chirurgicală prezintă riscurile ei, cele mai frecvente cauze de mortalitate fiind reprezentate de șocul septic, insuficiență multiplă de organ, insuficiență cardiacă, sepsis, șoc cardiogenic [17].

\section{CONCLUZII}

Se recomandă, pe cât este posibil, abordarea conservativă, cu inițierea tehnicilor chirurgicale după stabilizarea nou-născutului și chiar depășirea perioadei neonatale. Aceste cazuri necesită o abordare multidisciplinară, chirurgicală și reanimare neonatală, supraviețuitorii fiind urmăriți de către pediatri și medicul generalist pe toată durata vieții.

Conflict of interest: none declared Financial support: none declared

\section{BIBLIOGRAFIE}

1. Carmi R, Boughman JA. Pentalogy of Cantrell and associated midline anomalies: a possible ventral midline developmental field. Am J Med Genet. 1992;42(1):90-5.

2. Cantrell JR, Haller JA, Ravitch MM. A syndrome of congenital defects involving the abdominal wall, sternum, diaphragm, pericardium, and heart. Surg Gynecol Obstet. 1958;107(5):602-614.

3. Toyama WM. Combined congenital defects of the anterior abdominal wall, sternum, diaphragm, pericardium, and heart: a case report and review of the syndrome. Pediatrics. 1972;50(5):778-792.

4. Brochut AC, Baumann MU, Kuhn A, et al. Pentalogy or hexalogy of Cantrell? Pediatr Dev Pathol. 2011;14(5):396-401.
5. Zhang X, Xing Q, Sun J, et al. Surgical treatment and outcomes of pentalogy of Cantrell in eight patients. J Pediatr Surg. 2014;49(8):1335-1340.

6. Blackburn S. Maternal, Fetal, \& neonatal physiology-E-book: a clinical perspective. Elsevier Health Sciences, 2017.

7. Avroy FA, Martin RJ. Neonatal-perinatal medicine: diseases of the fetus and infant, 10th ed. Elsevier Saunders, 2015.

8. Jnah AJ, Newberry DM, England A. Pentalogy of Cantrell: Case Report With Review of the Literature. Adv Neonatal Care. 2015;15(4):261-268.

9. Suehiro K, Okutani R, Ogawa S, Nakada K, Shimaoka H, Ueda M, Shigemoto T. Perioperative management of a neonate with
Cantrell syndrome. J Anesth. 2009; 23(4):572-5.

10. Restrepo MS, Cerqua A, Turek JW. Pentalogy of Cantrell with ectopia cordis totalis, total anomalous pulmonary venous connection, and tetralogy of Fallot: a case report and review of the literature. Congenit Heart Dis. 2014;9(4):E129-134.

11. Wen $L$, Jun-lin $L$, Jia $H$, et al. Cantrell syndrome with complex cardiac malformations: a case report. J Pediatr Surg. 2011;46(7):1455-1458.

12. Liu Y, Yang J, Jin Z, et al. One-stage surgical correction in pentalogy of Cantrell with left ventricular diverticulum. J Card Surg. 2014; 29(3):413-416. 
13. Usha MK, Mahimaiha J, Shivanna DN. Incomplete pentalogy of Cantrell: single stage repair. Heart. 2012 Aug;98(15):1183.

14. Magadum S, Shivaprasad H, Dinesh K, et al. Incomplete Cantrell's Pentalogy - A Case Report. Indian J Surg. 2013;

75(Suppl 1):350-352.

15. Czeizel A. Schisis-association. Am J Med Genet. 1981;10(1):25-35.

16. Sakasai $Y$, Thang BQ, Kanemoto $S$, et al. Staged repair of pentalogy of Cantrell with ectopia cordis and ventricular septal defect. J Card Surg. 2012;27(3):390-392.

17. de Rubens Figueroa J, Sosa Cruz EF, Díaz García L, et al. Cardiac malformations in patients with pentalogy of Cantrell and ectopia cordis. Rev Esp Cardiol. 2011;64(7):615-618.

18. Bagabir HA, Azhar AS. Pentalogy of Cantrell: first case reported in Saudi Arabia. Ann Saudi Med. 2014;34(1):75-77.

19. Pachajoa H, Barragán $A$, Potes $A$, et al. Pentalogy of Cantrell: report of a case with consanguineous parents. Biomedica. 2010;30(4):473-477.

20. Lin J, Durham MM, Ricketts R, et al. Hepatic pulmonary fusion: two cases with diaphragmatic hernia and one case with Pentalogy of Cantrell. Fetal Pediatr Pathol. 2012;31(6):401-409.

21. Sowande OA, Anyanwu LJ, Talabi AO, et al. Pentalogy of cantrell: a report of three cases. J Surg Tech Case Rep. 2010;2(1):20-23.

22. Balderrábano-Saucedo N, Vizcaíno-Alarcón A, Sandoval-Serrano E, et al. Pentalogy of Cantrell: Forty-two Years of Experience in the Hospital Infantil de Mexico Federico Gomez. World J Pediatr Congenit Heart Surg. 2011;2(2):211-28.

23. Atis A, Demirayak G, Saglam B, et al. Craniorachischisis with a variant of pentalogy of Cantrell, with lung extrophy. Fetal Pediatr Pathol. 2011;30(6):431-436.

24. Jagtap SV, Shukla DB, Jain A, et al. Complete Pentalogy of Cantrell (POC) with Phocomelia and Other Associated Rare
Anomalies. J Clin Diagn Res. 2014;8(5):FD04-5.

25. Unal S, Cakmak Celik F, Ozaydin E, et al. A newborn with pentalogy of Cantrell and pulmonary hypoplasia. Anadolu Kardiyol Derg. 2009;9(6):519-520.

26. Mallula KK, Sosnowski C, Awad S. Spectrum of Cantrell's pentalogy: case series from a single tertiary care center and review of the literature. Pediatr Cardiol. 2013; 34(7):1703-1710.

27. Steiner MB, Vengoechea J, Collins RT. Duplication of the ALDH1A2 gene in association with pentalogy of Cantrell: a case report. J Med Case Rep. 2013;7:287.

28. Di Spiezio Sardo A, Paladini D, Zizolfi B, et al. Pentalogy of Cantrell: embryofetoscopic diagnosis. J Minim Invasive Gynecol. 2013;20(2):248-251. 